\title{
EMPLOYERS' ASSOCIATIONS IN THE PORT OF LIVERPOOL, 1890-1914*
}

The most dramatic agitations and triumphs of the "new" unionism in the late nineteenth and early twentieth centuries, together with its reversals and defeats by an organised employers' counter-offensive, occurred on the waterfront at British ports. The reasons for the revival and unsteady continuance of trades unionism in the ports at this period have been well detailed, ${ }^{\mathbf{1}}$ but serious analysis of the origins and growth of countervailing employer interest groupings in labour matters, at a time when shipowners felt compelled to meet organisation with organisation, has been altogether more sparse. ${ }^{2}$ The initial strategy of many employers was to set their face against unions "to get back to what they believed to have been the golden age of British labour", 3 with freedom for men to work on their own terms without union interference or, if not openly attacking unions, at least refusing to acknowledge their existence and come to terms with them as bargaining

* The research for this paper was supported by a grant from the Nuffield Foundation and is based on primary source material only recently made available. Acknowledgment is made to the following organisations for granting access to their records: British Shipping Federation, Employers' Association of the Port of Liverpool, Liverpool Steamship Owners' Association and Cunard Steamship Company.

1 See E. Hobsbawm, "National Unions on the Waterside", in Labouring Men (London, 1964), pp. 204-30, and H. A. Clegg, A. Fox and A. F. Thompson, A History of British Trade Unions since 1889, I: 1889-1910 (Oxford, 1964), pp. 55-96. For Liverpool see R. Bean, "Aspects of New Unionism in Liverpool, 1889-91", in: H. R. Hikins, Building the Union: Studies in the Growth of the Workers' Movement, Merseyside (Liverpool, 1973), pp. 99-118.

2 There is the eulogistic, official history of the Federation, L. H. Powell, The Shipping Federation (London, 1950), and J. Saville, "Trade Unions and Free Labour: The Background to the Taff Vale Decision", in: Essays in Labour History, ed. by A. Briggs and J. Saville (London, 1960), pp. 317-50, which deals with the defeat of the dock workers and seamen of Hull at the hands of the Shipping Federation.

${ }^{3}$ Speech of a Liverpool shipowner quoted in Liverpool Courier, 6 November 1913. 
agents. Conflict was endemic in the British shipping industry at this time, and employment relations were regulated unilaterally either by the employers or, in some cases where they were sufficiently strongly organised, by the unions. Yet, by the First World War employers had granted "recognition" and arrived at an accommodation with the unions over certain clearly defined areas of interest, with the result that henceforth industrial relations in the ports would be conducted via bilateral and joint regulation on a much more orderly and stable basis.

It is the purpose of this paper to examine for one specific port, and within the context of the structure and economic situation of the shipping industry itself, the movement towards collective action by employers and the need for their association which conditions in this period generated. It will also be shown why it was that some of the big liner companies had in fact no need of association in labour matters until 1911 and could continue to be self-sufficient, remaining outside the employers' federations and thereby seriously weakening them.

The Port of Liverpool is of particular interest because it was the country's leading export and overseas passenger port and its shipowners had taken an initiative in the adoption of steamships such that by the end of the 1870 's $30 \%$ of British steam tonnage was concentrated in the hands of Liverpool owners. ${ }^{1}$ Thus, as a result of the claimed "special character of the Liverpool shipping industry"2 its employers organised themselves in both trade and labour matters independently of other, national shipping bodies. The Employers' Labour Association, founded in February 1890, predated the establishment of the national Shipping Federation by six months and continued in existence until 1967 when it was wound up, having ceased to play an active part in local and national deliberations. Similarly, the new Employers' Association of the Port of Liverpool, set up in 1913, was sufficiently important to be granted separate representation in 1919 alongside the Shipping Federation on the reorganised National Maritime Board, the representative board for the industry at national level for regulating wages and employment conditions. ${ }^{3}$ It was not until 1967 that the Seafarers' Committee of this Employers' Association merged with the then Shipping Federation to form the present British Shipping Federation.

1 Report of the Liverpool Steamship Owner's Association, 1880.

2 F. F. Hunt, "The Owners", in: The Shipping World, ed. by J. A. Todd (London, 1934), p. 169.

${ }^{3}$ C. E. Fayle, The War and the Shipping Industry (London, 1927), p. 395.

However, the Liverpool Association had refused to join the original Board set up during the war. 
The first representative associations of employers in Liverpool shipping date from the early and mid nineteenth century. The oldest Liverpool organisation, the Liverpool Shipowners' Association, was formed in 1810 to protect the interests of sailing ship owners both in Parliament and elsewhere. ${ }^{1}$ Half a century later, in 1858 , the Liverpool Steamship Owners' Association was founded in order to represent the interests of the developing steam trade of the port by promoting more effectively steam interests to government and in parliamentary legislation, especially to resist the attacks of "mistaken philanthropists", ${ }^{2}$ and to the newly formed Mersey Docks and Harbour Board at a time when there was a need to adapt the port to the requirements of steam navigation. This association, characteristically, reserved its freedom to act separately from the Shipping Chamber of the United Kingdom and the Shipowners' Association of Great Britain, and likewise it did not seek to interfere with the individual freedom of its own members. It asserted that "the individual shipowner is entitled to carry on his own business in the manner which he believes will be productive of the best results". ${ }^{3}$ There was some drawing together of the two bodies in 1892, by which time a large number of sailing ship owners also ran steamers. It was decided, in view of the substantial differences between the interests of passenger liners and cargo steamers, ${ }^{4}$ to enrol the tonnage of members owning cargo steamships as well as sailing tonnage into the Shipowners' Association (and later in 1914 coasting steamship tonnage, in addition), ${ }^{5}$ thus delaying the demise of that body. ${ }^{6}$ Neither of these organisations attempted to regulate freights and regarded the fixing of wages, also, as a matter for individual rather than collective decision making.

Nevertheless, at times of crisis in the port such attitudes could be modified. In 1879 at a time of both depressed freights and passenger earnings an attempt was made for uniform, rather than separate, action on wages by employers. The Steamship Owners' Association called a joint meeting between themselves, the Shipowners' Association and the Liverpool Corn Trade Association with a view to agreement on

1 F. F. Hunt, loc. cit., p. 167

${ }^{2}$ L. H. Powell, A Hundred Years On: History of the Liverpool Steam Ship Owners' Association, 1858-1958 (Liverpool, 1958), pp. 13-14.

${ }^{3}$ Ibid., p. 16.

- Freight rates and passenger earnings are influenced by quite different forces. See H. J. Dyos and D. H. Aldcroft, British Transport (1971), p. 266.

5 Freight rates of coasting shipping were especially influenced by the rates of road competitors and the railways, which ran at artificially restricted rates.

6. F. F. Hunt, loc. cit., p. 168. 
the lowering of wages of dock labourers throughout the port. ${ }^{1}$ However, in view of the diverse interests represented no general agreement could be secured and the Steamship Owners' Association was left to take action independently; so that wages wore reduced at the deepwater North End docks, where the large Atlantic liners were berthed, but not at the South docks, where smaller steamers and the sailing ships of members of the Shipowners' Association predominated. ${ }^{2}$

The Steamship Association was also prepared to receive a deputation of dockers, after the event, for discussion of this wage reduction and by 1890 , during a port-wide dock strike, it was hearing from the local officials of the Sailors' and Firemen's Union their claims for a wage increase. Yet labour questions were clearly incidental to the major functions of the Association. There had been no attempt at standardisation of wages among Liverpool shipowners to ensure a uniform port rate for seamen, and it was said that the $\mathbf{1 8 9 0}$ claim for an enhanced monthly rate of $£ 410$ /- for firemen and $£ 4$ for sailors on certain voyage routes would require some shipowners to pay an increase of between $10 /-$ and $15 /$ - per month, whereas for others not more than $5 /-.^{3}$ Moreover, the Liverpool shipping paper the Journal of Commerce contended that shipowners in both sail and steam had always combined in "a more or less half-hearted manner" and that their associations, although they could be energetic, were more usually characterised by lethargy, "moral coma" and a "let-it-slide" policy. 4 Their approach was a highly respectable laissez-faire one, and they were rarely heard of other than at their annual general meetings. Thus, two separate bodies, too constrained in function, conservative and atrophied in attitude, would be unable to counter effectively the threat posed by the rapidly expanding and aggressive unionism of seamen and dockers at the end of the 1880 's.

In Liverpool there was in fact "utter and lamentable want of cohesion among employers" on labour matters. ${ }^{5}$ During two strikes of seamen and firemen in 1889 the leading Atlantic lines could not agree on a collective response to union demands for higher wages and a closed shop. Cunard was determined to hold out, fearing that otherwise

1 Liverpool Steamship Owners' Association, Minute Book, Vol. I, p. 565.

2 E. L. Taplin, Liverpool Dockers and Seamen 1870-1890 (Hull, 1974). The wage cuts were restored the following year.

${ }^{3}$ Liverpool Steamship Owners' Association, Minute Book, 17 March 1890.

- Journal of Commerce, 31 July 1890.

5 Ibid., 11 January and 22 August 1890 . Shipowners tended to act as "the pliant instruments of each other's destruction". London was said to be similar to Liverpool in this respect, and both were contrasted unfavourably with the North East Coast Association of Shipowners, which did not lack "exuberant vitality". 
"discipline would be at an end", whereas Inman and International was prepared to employ only union men and the White Star Line also willing to concede, provided it could obtain a better class of seamen than in the past. ${ }^{1}$ What finally brought the employers together into a temporary association to meet a specific emergency was the union's instruction to its members, under penalty of expulsion, not to sign on with any one company until all Liverpool shipowners had conceded their demands. This secondary boycott meant that concessions granted by individual companies would now be ineffective in securing labour, as the union had come "to assume the dictatorship". 2 Therefore, thirteen of the largest liner companies in Liverpool combined to subsidise a Cunard steamer for conversion into a floating boarding house from which strikebreakers, whom the owners were importing, could be taken as engaged for transhipment to outgoing vessels. ${ }^{3}$ These tactics proved effective and the seamen were defeated.

During the bigger crisis occasioned by the imminence of a full-scale strike of dockers throughout the port in the following year (1890), lasting for four weeks, this narrowly based, ad hoc and informal association of employers was to be replaced by a more widely embracing and permanent body. On this occasion the question in dispute was not so much one of money but rather, more fundamentally, was about "who shall control the shipping interests of the port - the owners or the men". ${ }^{4}$ The issues revolved around the enforcement of union rules which directly challenged and limited employer prerogative "and the rights and privileges which belong to capital"s over hiring practices, deployment and organisation of dock labour. ${ }^{6}$ As the employers saw it a stand had to be made against so determined and outrageous an attempt by a new union embracing a mass of casual labourers to extend the functions of trade unions beyond the confines of their "legitimate sphere". ${ }^{7}$ But the essential difficulty was that the divisive forces of economic competition and diverse interests among employers, trading in a variety of markets, made them reluctant to combine. They were competitors for both freights and passengers "who sat down

1 Cunard Papers, Minutes of Executive Committee, 23 January 1889, and Chairman's Letter Book, 12 June 1889.

${ }^{2}$ Liverpool Courier, 5 June 1889 and 4 December 1890. According to J. H. Wilson, the union's president, the shipowners were "whining like curs at the union tyranny".

3 Ibid., 21 June 1889.

4 Journal of Commerce, 7 March 1890.

5 Liverpool Daily Post, 14 March 1890

'See R. Bean, "The Liverpool Dock Strike of 1890", in: International Review of Social History, XVIII (1973), pp. 51-68.

7 Journal of Commerce, 27 March 1890. 
together uneasily for any purpose". ${ }^{1}$ Even when freight conference arrangements and passenger pool agreements were arrived at, to regulate and restrict severe competition, there was still instability and frequent rate wars. ${ }^{2}$

A number of factors relating to the structure of the industry and the economic position of the trade in which he engaged would influence a shipowner in deciding whether or not to concede a wage claim or resist a threatened strike. There were differences between sail and steam, tramp and liner shipping, and passenger and cargo services. The more leisurely methods of cargo handling on sailing ships had given way to the need for speedy turn-round and quick dispatch of steamships as a result of the high costs of keeping them in port. The basic division within steamship services was between the slower, irregular and more footloose tramp ships, used for transportation of bulk cargoes such as cotton, grain, timber and coal and the regular liners, emphasising speed and having scheduled sailings to specific ports. On the North Atlantic liner routes passenger traffic predominated, whereas on other routes there was less passenger traffic and more cargo carried. ${ }^{3}$ A delay to any ship would be expensive, but a delay to a ship full of passengers could be near-ruinous. ${ }^{4}$ Also, the charter rates and consequently earnings of tramp shipping fluctuated rather more widely than liner rates, ${ }^{5}$ but the tramp shipper had the option of withdrawing from business and laying-up when trade became too dull, whereas liners with fixed sailing dates had to continue. Tramp ships were not only generally slow, but also wage costs constituted their largest single item of total voyage costs. ${ }^{6}$ Finally, those steamship companies such as Cunard and Pacific Steam Navigation which had undertaken the obligation of mail contracts in return for a government subsidy ran their ships "with the regularity of railway trains", so that all other considerations had to be sacrificed to get the vessels away without delay on their due date and even their specified hour.?

Given these circumstances of particular and disparate interests, it was the challenge to employers' authority presented by union interference with the open and unrestricted labour-market arrangements

1 E. H. Phelps Brown, The Growth of British Industrial Relations (London, 1959), p. 265.

${ }^{2}$ H. J. Dyos and D. H. Aldcroft, op. cit., p. 270.

${ }^{3}$ Ibid., p. 260.

4 S. G. Sturmey, British Shipping and World Competition (London, 1962), p. 237.

${ }^{5}$ E. W. Zimmerman, Ocean Shipping (London, 1924), p. 497.

6 S. G. Sturmey, op. cit., p. 88 . On liners depreciation was the most important single item of cost.

7 Journal of Commerce, 9 June 1896 
for dock workers in the port, together with uncertainty about threatened, wider concerted action by dockers, seamen and other port workers, which enabled employers for a time to transcend their internal competitive divisions and unite to deal with labour problems collectively. Even so, their association was not all-embracing and was very much "reluctant", action having been "forced upon them". ${ }^{1}$ It was recognised that the combination could exist only so long as the many opposing interests comprising it remained mutual - the one point on which there was complete unanimity being the employers' "absolute and inalienable right" to employ whom they pleased, irrespective of union membership. ${ }^{2}$

The Employers' Labour Association was formed at a meeting of representatives of thirty of the principal steamship owners and twenty master stevedores and porters, who contracted to load and unload vessels, which between them employed a combined total of three fifths of the seamen and dockers in the port. ${ }^{3}$ It was to be a permanent, defensive body which professed "no desire whatsoever to interfere with the men's organisation". "The association with its own offices, labour master and secretary, who combined these duties with the secretaryship of the North Atlantic Passenger Conference, was to have an accumulated fund to resist strike demands and, through its agents, information regarding surplus labour throughout the country. During the dock strike it imported some 10,000 strikebreakers, ${ }^{5}$ housed on depot ships, to defeat the union. The requirements of mail steamers, which had to be got to sea at all costs, were given first priority from the resources of the association. ${ }^{6}$ However, apart from smaller firms at the South End, where the dockers' union had already established a sound footing by securing agreements prior to the strike, there were some important shjpowners such as Alfred Holt and R. P. Houston who had also agreed to the union rules and would not join the ELA. Holt engaged his dock labour directly, rather than through contractors, he recognised the seamen's union and was regarded by both waterfront unions as a considerate employer. ${ }^{7}$ Houston was a maverick shipowner who fought his way into various trades against entrenched Conference opposition. When the dock strike was extended and made general to

1 Ibid., 7 March 1890.

2 Ibid.

3 Liverpool Courier, 11 February 1890.

- Journal of Commerce, 1 March 1890.

- At a cost of $£ 32,000$. Royal Commission on Labour, Group B, Vol. II [C. 6795] (1892), Associations of Employers, "Answers to the Schedules of Questions".

- Cunard Papers, Chairman's Letter Book, 7 March 1890.

7 Royal Commission on Labour, Group B, Vol. I [C. 6708] (1892), q. 9669. 
include even these "friendly" employers, he met the dockers' refusal to load one of his ships by rolling up his sleeves and, with the help of his office staff, loaded it himself. ${ }^{1}$ During the strike he contributed towards a relief fund for the families of strikers. Those employers who acceded to the union's rules were denounced as "weaker brethren" by the leading shipowners, and after being let down by the union they had then to get by as best they could because the ELA refused to allow them to join the association retrospectively in order to obtain a share of the imported men. ${ }^{2}$

In fact, as the strike progressed the approach of the ELA became more intransigent. It countered the challenge of the union's rules by issuing a more restrictive set of its own, stipulating the conditions under which dock labourers would be employed henceforth. It refused to accept mediation by the Chamber of Commerce, or negotiate through the union, although ultimately it was prepared to meet a deputation of bona fide dock labourers and agree to some minor concessions in its published scale of terms and hours. By the middle of the strike it was reported that the ELA had abandoned hope of an amicable settlement and had decided to starve the men out, ${ }^{3}$ some of the leading transatlantic companies having recognised from the outset that "one thing seems certain - the men had not much money and cannot hold out long without outside help". ${ }^{4}$ At the termination of the strike, when the union had capitulated, the members of the Association would not take back men who wore the union "button" and required them all to sign a "document" agreeing to work harmoniously with non-unionists and importees. ${ }^{5}$

With the successful conclusion of the dock strike Liverpool shipowners were now confident of their strength to deal with labour disputes through their own resources, on a local basis. Thus, when the Shipping Federation was established in London later in the year as a fighting machine to counter strikes and "coercion" by waterfront unions, some steam and sailing ship owners in Liverpool joined on an individual

1 Liverpool Courier, 18 March 1890.

${ }^{2}$ Journal of Commerce, 28 March 1890.

${ }^{3}$ Liverpool Daily Post, 18 March 1890.

4 Cunard Papers, Chairman's Letter Book, 7 March 1890. When the magistrates voted to bring in the military during the strike the troops were victualled by Cunard, the cost of $£ 456$ being later reimbursed by the Mersey Docks and Harbour Board. Minutes of Executive Committee, 18 February 1891.

5 Liverpool Courier, 2 April 1890 . The requirement not to wear the button became less rigorously enforced in the subsequent months. 
basis, yet the majority "did not manifest any overwhelming anxiety to enrol". ${ }^{1}$ But although the predominant steamship companies in the port were anxious to preserve their independence and autonomy, nevertheless the (sailing) Shipowners' Association felt that membership of the Federation was desirable and that its tonnage should be entered en bloc. In particular, it maintained that if the Seamen's Union succeeded in its tactic of forcible organisation of ships' officers then "the position of master and servant would be entirely reversed". ${ }^{2}$ But its overtures met with such a meagre response from its membership (only $10 \%$ of whom agreed to enter their tonnage) that Federation membership on a group basis was not taken up, the Association's chairman commenting that "So long as they were out of trouble with any labour question no one cared to do anything". ${ }^{3}$ The fact was that in the event of further strikes outside labour could be supplied through ELA agents and usually there was enough local, "free" labour in a big port such as Liverpool to enable the owners to man their vessels without difficulty - indeed in the winter of 1890-91 the widespread unemployment was said to be "the best card in the pack" for keeping labour in its place. ${ }^{4}$

Obviously, however, it was desirable to have some working arrangement between two organisations, the ELA and Shipping Federation, both dedicated to the concepts of freedom of labour and freedom of contract, which recruited replacement labour on a country-wide basis. A formal alliance rather than full amalgamation was required to enable the Liverpool Association to retain its separate organisation and absolute control of labour matters on the Mersey. The Association took the view that labour conditions in Liverpool differed markedly from those in other seaports as better wages and more liberal treatment of seamen and dockers were given by Liverpool employers. ${ }^{5}$ It was indeed true that for seamen only a few shipowners in Liverpool insisted on sailors and firemen signing the Federation "ticket" agreeing to work with non-unionists, ${ }^{6}$ and that the increased wages granted in 1890 during a revival of trade were not withdrawn until 1893, despite a large fall in freights. Also, seamen in mail steamers and large passenger liners, where speed and quality of service were important competitive factors, had more or less constant employment, as well as receiving

1 Journal of Commerce, 29 October 1890.

2 Liverpool Courier, 20 March 1891.

3 Ibid., 24 March 1892.

4 Ibid., 23 January 1891.

5 Liverpool Courier, 9 March 1891.

${ }^{6}$ Royal Commission on Labour, Group B, Vol. I, q. 9753. 
higher wages than those employed in tramp and cargo vessels. ${ }^{1}$ Similarly, for dock labourers, although inter-port comparisons are difficult because of variations in methods of payment and labour organisation, it would appear that as compared with a daily payment for ordinary labour on ship of $5 /$ - in Liverpool the rate was $4 / 6 \mathrm{~d}$ in Grimsby and Hull. In Liverpool stevedores received a daily rate of $7 /-$, as opposed to $6 /-$ in London, all dock labour was engaged by the half day rather than the hour as in some other ports and Liverpool did not have the "plus and contract" systems to which the London dockers had objected. ${ }^{2}$ As a result of these differences it was claimed that frequent disturbances might arise if Shipping Federation vessels visiting Liverpool were to require wages and conditions, either on shore or afloat, which diverged from those of the ELA. This is why, in arriving at a working agreement, it was insisted that the ELA should act as the district committee of the Federation for the Mersey and have absolute control of labour in the port.

The agreement provided that in the event of a strike the ELA could draw on the Federation's ticket men in every port in the United Kingdom, in addition to its own resources, and that the Federation would act as the agents of the Association in all ports except on the Mersey. The ELA vessels in these ports would be subject to the instructions of the appropriate district committee of the Federation. Financially the two bodies were not to be responsible for each other's costs incurred during strikes by way of wages, conveyance and accommodation of dockers and seamen, or for payments made to members for indemnities or compensation. The Federation would meet the annual establishment expenses of both the ELA and Mersey District Committee of the Federation (on which by 1896 there was equal representation), and which shared office and secretarial facilities. The ELA was to contribute, in proportion to the ratio of its tonnage to total Federation tonnage, towards an agreed, maximum annual expenditure

1 Journal of Commerce, 13 and 30 January 1889. Wage cost was a more important part of total costs for tramps than for liners.

${ }^{2}$ For these wage comparisons see Liverpool Mercury, 11 March 1890. The enhanced rates in Liverpool probably owed something to the greater degree of work specialisation, skills and speeds required as a result of the early predominance of steamships, passenger interests and export work. With regard to contract work the rules of the National Union of Dock Labourers in Liverpool stipulated that "no member [...] will be allowed to take Second Lump or Sub-Contract, nor work for any man so employed". National Union of Dock Labourers, Toxteth Branch, No. 5, Working Rules (n.d.), British Library of Political and Economic Science, Webb Trade Union Collection, Section C, Vol. 46. 
by the entire Federation of $£ 15,000 .{ }^{1}$ In fact, the ELA as a "co-operator" paid about one half of the contribution of a full group member and yet was entitled to receive almost the same day to day services. For more than half a century it obtained the services of the Federation at very low cost as its contribution in 1964 was still based on a proportion of the original limit of $£ 15,000$, despite very much greater actual working expenses incurred by the Federation.

Notwithstanding these similarities of function and close working arrangements there was an important difference between the ELA and the Federation. Until the First World War the Shipping Federation disclaimed any interest in wage fixing, the matter being left "severely alone". Wages would be determined via freedom of contract on the basis of demand and supply. ${ }^{2}$ In contrast, the ELA, with a smaller geographical coverage, laid down wage schedules both for seamen and for ship and quay men on the docks. It required individual members to submit any new demands made by their labour force for the consideration of the Association. ${ }^{3}$ It did not, however, welcome approaches from the intermediaries of trade unions and would not reply in 1896 to a communication from the National Union of Dock Labourers enclosing a copy of its revised Port working rules, which concerned the more conspicuous wearing of the "button" at work. ${ }^{4}$ But it stated that it was always prepared to receive deputations directly from its own employees. In the event, the ELA did not become a negotiating body and discovered that it had little effective control over member firms who wished to raise wage rates independently. In 1898, in response to demands by the Sailors' and Firemen's Union, both the Allan and Dominion Lines had granted an increase without consulting the Association. When asked for an explanation Allan claimed a special position as a mail carrier and Dominion stated more bluntly that it found itself constrained, by a possible strike for an uncertain period of a passenger ship, either to pay the increase or have the vessel detained..$^{5}$ In any case, it was disputed whether the rules applied to

1 ELA, Minute Book, No. 1, (revised) "Terms of Agreement made between the Employers' Labour Association and The Shipping Federation Ltd.", 15 May 1896. By 1925 the ELA contribution was $£ 1,862$, which the Federation felt to be inadequate. 'The ELA's position was that its members also belonged to the new Employers' Association of the Port of Liverpool and if Federation calls on them were increased they would then withdraw fron the ELA and adhere to the one larger organisation. ELA, Minutes, 30 June 1925.

2 Royal Commission on Labour, Group B, Vol. I, q. 11528, and Vol. II, Associations of Employers, "Answers to the Schedules of Questions".

${ }^{3}$ Ibid.

4 ELA, Minutes, 11 August 1890.

5 Ibid., 9 December 1898. 
seamen's wages, given that the Steamship Owners' Association also adjusted sailors' wages on a separate basis. These explanations were apparently accepted by the ELA.

The ELA was hardly in a position to expel deviant companies because it had been faced with defections and a severe loss of membership. The original fifty members in 1890 were reduced to thirty two by the following year and in 1909 comprised a mere thirteen. ${ }^{1}$ Once the initial labour crisis in the port had passed and the attendant uncertainties lessened, members began to drift away. Lacking real authority in wage matters, the Association was regarded by its remaining members as a form of mutual insurance and a backstop for requisitioning labour during a strike, when all else failed. The expenses incurred by a member firm during a dispute would be reimbursed by the Association's levying the whole of its membership, usually at the rate of $1 / 2 \mathrm{~d}$ or $1 / 4 \mathrm{~d}$ per ton of their individual tonnage. Under certain circumstances the levies were allowed by the Income Tax Commissioners as a trade expense. ${ }^{2}$ The ELA was even prepared to allow the Papayanni Line into membership after its steamers had been struck, although it would not pay the actual costs of the strike. But it did secure from the Federation replacement dock labourers from London and Hull to work the company's vessels, together with a $25 \%$ discount on their fares refunded by the London and North Western Railway Company. ${ }^{3}$

In effect, the ELA had become a single-purpose organisation to supply "scab" labour and was in abeyance for much of the time, meeting for action only every few months if a dispute was threatening. It had also become more cautious and noticeably less confident, instructing its labour master "to refrain from any course that might be provocative", and being opposed to distributing along the docks inflammatory handbills sent from the Federation in London. ${ }^{4}$ Thus, by providing an intermittent rather than a continuous service, the Association had difficulty in holding its members together. Except during a critical, port-wide labour confrontation its members did not feel that their interests were so interdependent that they had to stand together and act in unanimity. Moreover, in many typical disputes after 1890 the ELA was "comparatively helpless" to render assistance

1 Ibid., 31 March 1909. These firms were mainly medium sized and between them represented about one million tons of shipping.

2 Ibid., 2 February 1915.

${ }^{3}$ Ibid., 24 January 1900 . This railway company owned the Garston dock at the South End and was noted for its opposition to trades unionism on principle.

See E. H. Phelps Brown, op. cit., p. 168.

4 ELA, Minutes, 4 and 18 September 1896

${ }^{5}$ Liverpool Weekly Post, 23 October 1890. 
because, with the union's strength depleted, they were not full-scale strikes but rather single-day walkouts, or guerilla warfare and petty annoyances by particular work groups on single ships, often as a result of "ca'canny" practices designed to regulate the effort bargain. The Association suffered a further setback in 1894 when its secretary embezzled $£ 500$, which necessitated an additional levy on the membership to recoup the loss. ${ }^{1}$

However, the basic source of weakness in the ELA stemmed from secessions by the large liner companies, which returned to an independent approach towards labour matters. Strength and cohesiveness within an employers' association requires discipline and the surrendering of a certain amount of enterprise autonomy, which the liner companies were not prepared to accept for more than a limited period. They soon discovered that the ELA firms' policy of making no distinction between freemen and union men, by engaging unionists and non-unionists indiscriminately, tended to exacerbate the many minor agitations which the union kept up at the Northern docks. Early in 1891 the union in Bootle had once again made the wearing of the button or badge at the stands compulsory and members were refusing to work alongside non-unionists, thus reopening the whole question of recognition. ${ }^{2}$ The immediate response of seven of the largest companies at the North End was to put placards along the docks indicating that no one wearing the button would be engaged, and where the men refused replacements were secured from the ELA. ${ }^{3}$ They were now following the lead of Cunard, which all along had employed no "buttonists" whatever, and whose loading operations therefore proceeded without friction. ${ }^{4}$

More significantly, the companies at one stage took further action on their own account by engaging numbers of permanent or "constant" stevedores and hatchmen, equal to their minimum labour requirements, on a weekly basis instead of casually by the half day. To safe-

1 Cunard Papers, Minutes of Executive Committee, 5 September 1894. The first secretary had resigned on appointment as Montreal agent to the HamburgAmerican company and was succeeded by the Association's labour master (outside executive officer), who embezzled the money.

2 Liverpool Weekly Post, 14 February 1891.

${ }^{3}$ Liverpool Courier, 10 and 13 February 1891.

${ }^{4}$ Liverpool City Council, Full Report of the Commission of Inquiry into the Subject of the Unemployed in the City of Liverpool, 1894, Evidence, q. 123, and Cunard Papers, Minutes of Executive Committee, 19 February 1890. Cunard was also the only line in New York which had an independent gang of nonunionists. The reaction of its New York agents to a threatened dock strike was to increase the number of permanent men on monthly wages so far as possible, consistent with economy. Ibid., 3 February 1897. 
guard themselves against regular men leaving without notice some of them also deducted by instalments a week's pay, to be retained in hand and given back when employment was terminated. ${ }^{\mathbf{1}}$ For the engagement of remaining cargo men employed by the large firms such as Cunard, White Star and Inman and International there was a system of permanent numbers retained by the men from week to week, so that all men holding permanent numbers were taken on (for quay work, if no cargo loading was needed) before resort was had to the casuals, ${ }^{2}$ i.e. the permanent men and those with constant numbers were the aristocracy of dock labour and had little in common with the mere casuals. The object of the permanent and preference labour system was, of course, not only to retain a supply of reliable and experienced dock workers but to ensure that they would look to the companies rather than to the union for greater security of employment. It also drove a wedge between the men and their union in that the union prohibited members from accepting employment at weekly wages, those who did so having to resign their membership. ${ }^{3}$

Furthermore, stevedores employed by Cunard were paid a small differential over the official ELA rates, and seamen had practically constant employment on the Atlantic routes, varied by repair and maintenance work in the shore gangs when the steamers were laid up in winter. Efficient firemen were granted a bonus of $5 /-$ a month in addition to their wages on the fast New York ships, subject to good conduct. ${ }^{4}$ In addition, Cunard, West India and Pacific and the Allan line all had their own benefit societies for the men which provided for payment at death or in case of accidents and, sometimes, sickness. ${ }^{5}$ As a result of these arrangements the large liner companies were enabled to be self-sufficient in labour requirements. They could circumvent the union and also remain independent of the ELA, from which they gradually resigned - Cunard maintaining that "they were not likely to derive any advantage from it, at all comparable with the costs to the company". ${ }^{6}$ In the case of a seamen's strike these companies could make up the places of the crew out of their own resources from the shore gangs, as had happened during the 1889 strikes, and

${ }^{1}$ Liverpool Courier, 1 April and 5 November 1890. These practices were fiercely opposed by the union and were largely discontinued.

2 See evidence of Cunard and Inman and International in the above Full Report, pp. 12, 15.

${ }^{3}$ Liverpool Courier, 5 November 1890.

4 Cunard Papers, Minutes of Executive Committee, 18 September 1889.

5 Journal of Commerce, 20 April 1891. In the hazardous conditions of waterfront employment such benefits would not lightly be discarded.

- Cunard Papers, Minutes of Executive Committee, 24 April 1895. 
the regularity and interchangeability of employment, together with paternalistic treatment accorded to their longer serving seamen and dockers, made their employees unlikely to take precipitate action. But arrangements making for individual company autonomy in labour matters were only applicable to liner firms which were large employers of seafaring and waterside labour. They had sufficient volume of business and regularity of sailings to enable them to employ permanent and preference dock workers and a large shore staff, unlike the many smaller firms whose few sailing vessels or steamers often had no regular sailings.

These smaller and medium-sized companies, lacking the resources of the large-employment concerns to resist union demands by their own unaided efforts, and more vulnerable to labour pressure, had either to attempt to hold out by retaining membership of the ELA, or Federation, or else capitulate and recognise the unions. If they were engaged in coasting or tramp shipping and might require the services of a national organisation at various ports of call in addition to that at their home base, and required labour costs to be kept at rock bottom, then they tended to belong directly to the Mersey District of the Shipping Federation. ${ }^{1}$ At the South docks the forty smaller firms of both shipowners (some of whom were ELA members) and independent master stevedores, competing for contract work there, did recognise the dockers' union and its rules and gave preference of employment to union members. In these docks shipowners without "appropriated" berths and quay space for their own exclusive use, which liner companies such as Cunard and Inman possessed at the North End, ${ }^{2}$ often had their ships waiting in the river for accommodation. This factor, together with the nature of some of the cargoes carried including fruit, sugar and rice, which required rapid dispatch to avoid spoilage and the incurring of demurrage, ${ }^{3}$ made them particularly vulnerable to union pressure and sudden withdrawals of labour. In addition, employers wanted competent dockers in order to avoid delays, and if they did not have their own supply of permanent and preference labourers they went to the union, as representing the more capable and experienced workmen who were committed to the industry and had a stake in it.

The position was similar in Birkenhead, where the union was also recognised. This was the main export section of the port for Eastward

1 Journal of Commerce, 11 July 1911.

2 See Abstract of Evidence, taken before a special committee of the Mersey Docks and Harbour Board in reference to the Dock Accommodation of the Port, 1872, pp. 8, 50, and Porcupine, 25 August 1877.

${ }^{3}$ Liverpool Courier, 13 July 1905. 
cargoes, where more specialised labour was required and in which there was said to be a lack of organisation among shipowners. ${ }^{1}$ In Birkenhead the union insisted that foremen who determined the makeup of gangs and the pace of operations must belong to the union. Its rules further specified the number of men to a gang, as well as the quantity of cargo to be put in the slings and the speed at which it should be tallied-in, so as to prevent undermanning and overwork. ${ }^{2}$ Any infringement of these rules meant that the foreman was hauled before the union's branch committee and fined. The remaining companies which used the Birkenhead and South docks, such as Harrisons, Bibby and the Hall Line - lacking the resources of the Atlantic liner firms to be able to by-pass union organisation at will, yet sufficiently large in size and volume of business to resist its total dominance these recognised the "button", but reserved the right to select their own foremen. They held together, using labour supplied by the ELA as a standby, to resist further attempts at union encroachment. ${ }^{3}$

It is therefore apparent that by the first decade of the twentieth century, in contrast with the broad polarisation of waterfront labour relations in 1890 into a union and an employer grouping, characterised by mutual alienation, there had been a loosening of organisational ties among employers in labour matters, together with some regrouping on the basis of type of business concern and scale of operations. Moreover, in some parts of the port the employers and the dockers' union had come to terms with each other in an attempt to create more order and stability in industrial relations. By 1903 the master stevedores had deserted the ELA and through their own Master Stevedores' and Porters' Association had negotiated a written agreement with the National Union of Dock Labourers. This recognised its rules and provided for continuation of work without interruption in case of dispute, pending arbitration by a joint committee composed of an equal number of union and employer representatives. ${ }^{4}$ In contrast, the transatlantic liner companies, like those in New York, ${ }^{5}$ stood firm and refused to have any dealings with the unions. But in the fixing of rates of pay and allowances they set the pace throughout the port.

1 Journal of Commerce, 20 October 1893.

2 Ibid.

${ }^{3}$ A long, but unsuccessful, strike by the rank-and-file over the foremen question took place at $T$. and J. Harrisons, the largest employer of dock labour at the South End, who responded by importing ELA strikebreakers. It was led by James Larkin, one of the company's foremen who was later to become a militant union organiser in Ireland. See Liverpool Courier, July-August 1905.

4 National Union of Dock Labourers, Port Working Rules, Liverpool Branches, 1903, Webb Trade Union Collection, ibid.

- Compare C. Barnes, The Longshoremen (New York, 1915), p. 127. 
Cunard also made its own arrangements to circulate to other steamship companies a blacklist of seamen and stewards who were not to be employed. ${ }^{1}$ Between these two extremes stood the ELA with a more pragmatic approach and a dwindling membership, some of whom granted at least a union preference of employment (although the Association would not negotiate union agreements). The Shipping Federation, representing no more than $20 \%$ of the port's shipping interests, ${ }^{2}$ mainly tramping vessels, still adamantly refused to grant union recognition, accept the "button", or determine wage rates. Both these employers' organisations were therefore followers of the predominant shipping interests rather than initiators, and in labour matters they pursued an entirely passive and negative policy. Finally, there remained a few important non-association lines which had always enjoyed good relations with the union although they did not have written agreements, and their existence at the South docks prevented the ELA members there from attempting to withdraw recognition of the dockers' button in 1903 following a period of renewed union militancy. ${ }^{3}$ Such lack of cohesion between the various employer groupings and independent firms throughout the port meant that there remained a great diversity of waterside conditions and allowances, as well as adjustment of disputes on a piecemeal basis. The problems thereby created were brought sharply into focus by the second wave of "new" unionism and upsurge in labour activity, in 1911.

\section{III}

In the early summer of 1911 a number of strikes for an increase in seamen's pay occurred in Liverpool during a year of revitalised trade, subsequent upon one of the worst periods of depressed conditions for both tramp and liner services in the history of the shipping industry. ${ }^{4}$ Pressure was put initially upon the mail steamers, as the point of least resistance, and then extended to the other liner firms. An ad hoc meeting of leading Liverpool shipowners had agreed to allow each company freedom to make its own settlements "which the requirements of its individual trade warranted" ${ }^{5}$ This decision proved disastrous for the shipowners, for not only was each individual settlement made by

1 Cunard Papers, Minutes of Executive Commitlee, 30 June 1910.

2 Shipping Federation (Mersey District), Minutes, 28 August 1919.

${ }^{3}$ ELA, Minutes, 29 May and 10 July 1903. Elder Dempster, Pacific Steam Navigation (up to 1905) and the Booth and Holt lines were leading non-ELA companies which used the South docks.

${ }^{4}$ H. J. Dyos and D. H. Aldcroft, op. cit., p. 268.

5 Journal of Commerce, 28 June 1911. 
Cunard, White Star, American Dominion and other lines used as a lever to force similar concessions elsewhere, but it also generated demands in other ports. Members of the Shipping Federation in other parts of the country complained about being left exposed by the capitulation of the Liverpool owners at the first onslaught, instead of their having approached the Federation with a view to a definite line of united action. ${ }^{1}$ Moreover, the seamen then extended their disputes on the Mersey unofficially, even when their own demands had been met, to encompass sympathetic strikes on the Atlantic steamers on behalf of the dockers' organisation, which was pressing strongly for recognition and the sole employment of union labour throughout the port. The shipowners were "caught napping", and to avoid further disruptions Pacific Steam Navigation and the Nelson Line agreed to grant recognition to all unions. Given such hitherto "unheard of concessions" a new initiative on the part of the shipowners was clearly needed. Not surprisingly it came from Cunard, which at that time was the leading British passenger line and which had been severely affected by the disputes, no longer being able to rely on the loyalty of its own labour force.

The basic problem which the shipowners had to face concerned the wave of sectional and sympathetic strikes which were occurring that summer in most of the major ports throughout the country. Such simultaneous and widespread stoppages at a time of buoyant demand and falling unemployment meant that the well-tried policies of diverting ships to strike-free centres, and defeating the unions by replacing their members with free labourers, could not so readily be adopted. The alternative "fighting" strategy favoured by the Shipping Federation of meeting further trouble by running some ships but laying up others and indemnifying their owners, and thus by deliberate adjustments to demand and supply allowing unemployment to reduce wage pressure, ${ }^{2}$ did not appeal to the Liverpool liner companies which were not in any way associated with the Federation. It is true that the British lines had lost their predominant position held in the Atlantic passenger trade in the 1870's and 1880's and that in the pre-1914 period German shipping provided the most formidable competition to British liner services. ${ }^{3}$ Nevertheless, in the first half of 1911 British shipowners had successfully deprived continental and American lines in the North Atlantic Passenger Conference of a portion

1 Ibid., 30 June 1911.

2 Ibid., 12 July 1911.

3 S. G. Sturmey, op. cit., p. 33 
of their traffic;" in particular, Cunard was "making more money than anybody else". ${ }^{2}$ The companies did not wish to see this competitive advantage jeopardised by continuing labour disputes.

Moreover, there had been a growing tendency amongst lines towards amalgamation and inter-working arrangements for mutual benefit. It was the policy of Cunard "to cultivate by every means in its power such relations with competing lines as will enable rates, whether of passage money or of freights, to be maintained at a reasonably profitable level". ${ }^{3}$ This company had also embarked on a big programme of expansion and was now less willing to isolate itself from other companies because it was diversifying its interests into the Canadian trade, by acquiring the passenger and cargo business of the Thompson Line, and into the Indian trade through its acquisition of the Anchor Line. Combination rather than competition was, in fact, inherent in the character of liner business, which required regular custom in return for fixed sailings; over the period 1897-1910 the proportion of the port's total trade handled by regular lines had increased from $64 \%$ to $79 \%{ }^{4}$

Given the need at this period to retain momentum and stability in trading conditions, the recurrent and sectional disputes throughout the port of Liverpool had put irresistible pressure on employers to counter them by means of a collective response - they all stood together. In response to a request from the dockers' union to Cunard for a port conference to discuss labour matters, Alfred A. Booth, the young and recently appointed chairman of the company, ${ }^{5}$ instead of adopting the

1 Of the continental lines in the Pool Norddeutscher Lloyd, Hamburg-America, Holland-America and Red Star, with a claim of $62 \%$ of the total traffic in the pooling agreement actually carried 13,844 fewer passengers than their quota allowed. There was a similar shortfall by the American and Anchor Lines whereas, of the Liverpool companies, Cunard carried 4,123, White Star 3,119, Dominion 7,949 and the Allan Line 488 passengers more than their respective shares of the total traffic. Journal of Commerce, 15 August 1911. Freight rates also yielded "handsome returns" on capital invested at this time. Ibid., 1 January 1912.

2 Cunard Papers, Chairman's Letter Book, 1 April 1911.

3 Chairman's Speech to Cunard Board, quoted in Journal of Commerce, 7 April 1911.

'Liverpool Shipowners' Association, Annual Report 1910.

5 Alfred A. Booth was the nephew of Charles Booth, the social reformer, and had been a Cambridge Wrangler. He entered the family shipping firm as a director and then came onto the Cunard Board in 1901, being elected chairman in 1909 at the age of thirty seven. The labour policy of the Booth Line was to seek loyalty and efficiency from their men in return for good wages and permanency of employment. See "Booth Men and Labour Relations", in A. H. John, A Liverpool Merchant House (London, 1959). 
usual course of referring the communication to the general manager to send a negative reply, called together representatives of the leading employers in the passenger and cargo business. At this meeting a subcommittee was appointed, with Booth as chairman, to negotiate directly with the men. ${ }^{1}$ The outcome was that an agreement was signed with the dockers' union by thirty deep-sea shipowners and twenty master stevedores to adopt on a port-wide basis union hours and rates of pay, to allow men to wear the button at the stands and for employers not to discriminate in favour of non-union labour. ${ }^{2}$ The union thus gained the recognition it had long sought at the Northern docks and its secretary, James Sexton, thought the agreement "magnificent". ${ }^{3}$

For their part the employers did not pledge themselves to employ union labour exclusively and retained the right to give preference numbers to regular men. They also obtained from the union a written undertaking not to interfere with the method of working cargo, on ship or quay. The agreement thereby set limits to union encroachment because employer prerogative, as opposed to the full adoption of the union's working rules, was still retained in the organising and deployment of labour. No change in working practices could be introduced without the agreement of a joint committee composed of an equal number of employer and union representatives, i.e., the employers could veto any proposed alterations. This joint committee would be permanent and adjust future disputes about pay, conditions of work and the interpretation of the agreement. Pending its decision no work stoppage was to take place. Essentially, therefore, the agreement sought to reduce the incidence and unpredictability of strikes through union acceptance of a procedural arrangement. The men would now be expected to frame their grievances with their officials and submit them through the proper channels. The union had assumed joint responsibility through its equality of representation on the committee, so that the emphasis was on both parties adhering to the terms of the agreement, which the employers wished to see interpreted in "a very binding manner". 4

As a result of the granting of recognition it was intended that the hand of the union officials in disciplining the rank-and-file would be strengthened. Subsequent agreements in 1912 and 1915 provided for

1 Cunard Papers, Minutes of Executive Committee, 20 July 1911.

2 Ibid., Booth files, "Agreement as to Terms and Conditions of Dock Labour in the Port of Liverpool", August 1911 (the "White Book").

${ }^{3}$ Liverpool Daily Post and Mercury, 22 August 1911.

4 Journal of Commerce, 5 July 1911. 
one month's notice of a stoppage of work to be given ${ }^{2}$ and a bond of $£ 2,000$ to be deposited by both parties as a guarantee of faithful performance - any fines or damages awarded by the Joint Committee to be paid out of the deposit of the party failing to meet its obligations, the bond then being made up again to the original amount. ${ }^{2}$ However, recognition of both the dockers' and seamen's unions ${ }^{3}$ did not mean that Liverpool employers had weakened in their approach to labour problems. On the contrary, their newly acquired unity had enhanced and consolidated their position. When sectional disputes by dockers and seamen in support of the railwaymen broke out again in August 1911 at some of the smaller shipping companies, despite the efforts of union officials "to do all in their power to get the men back to work who had broken the agreement", a general closing down of cargo work and a lockout of the men at the docks was proclaimed by employers in support of their "brother" shipowners. ${ }^{4}$ For several days until the railway strike was settled and the Liverpool lockout withdrawn 28,000 dockers and 12,000 sailors and firemen were either locked out or on strike.

The employers had sought to mitigate the disruptions to the trade caused by sectional, unofficial and sympathetic strikes through union recognition on a comprehensive basis and the device of the procedural agreement. The shipowners could, and did, imperil this hard-won recognition by threatening to dissolve the Joint Committee at the first sign of serious trouble. ${ }^{5}$ As a result, Sexton would not allow the dockers in Liverpool to answer the call of the Transport Workers' Federation in 1912 for a national strike in support of the London dockers ${ }^{6}$ - in view of the union's "moral obligations" to the shipowners to carry out their agreement. Moreover, the Liverpool employers were considering a further means of stabilising the port labour situation on a longer-term basis, namely through the decasualisation of dock labour. Alfred Booth had sent Cunard officials to investigate the arrangements for greater regularisation in the dock labour markets at Hamburg and London, ${ }^{7}$ and he wrote to the Chairman of the White Star Line:

"if there is a strike in London I am told that it will be due to the

1 Ibid., 12 June 1912.

2 "Agreement between the Employers' Association of the Port of Liverpool and the National Union of Dock Labourers and Riverside Workers", 19 February 1915.

${ }^{3}$ Journal of Commerce, 15 May 1912.

4 Liverpool Daily Post and Mercury, 15, 18 August 1911.

5 Journal of Commerce, 16 July 1912.

- C. Watney and J. A. Little, Industrial Warfare (London, 1912), p. 98

7 Cunard Papers, Chairman's Letter Book, 14 July 1911. 
discontent and unrest amongst the casual men. The more regular men of the Port of London authority would stick to their work unless driven out by the others. It seems to me that we must adopt a similar solution in Liverpool."1

As chairman of the Joint Committee Booth took a leading part in negotiating arrangements for registration of dockers, to reduce the reserves of labour by eliminating fresh entries, and in the setting up of a clearing house to improve labour mobility throughout the port. ${ }^{2} \mathrm{He}$ also won over some hesitant shipowners to the scheme. ${ }^{3} \mathrm{By}$ its power to issue and withhold tallies the Joint Committee would practically control the labour supply of the port and, as the employers saw it, "would make for discipline and proper control of dock labour". The tallies gave the employers a control over the men distinct from any control which might be exercised over them by the union. ${ }^{4}$ When the scheme was introduced the men in Birkenhead struck against it, complaining that it had not been brought by the union to the rankand-file for ratification. ${ }^{5}$ Many of them felt that their struggle against the employers had now given way to a struggle against a coalition of union officials and employers. Sexton, who had written privately to Booth apologising for his "awkward team" of union negotiators (he sometimes having to apply the "mailed fist" to them when they were not amenable to reason ${ }^{6}$ ), was referred to by the strikers as "Slimy Jim" and castigated as a "creature of the employers". ${ }^{7}$ Nevertheless, the Birkenhead men were defeated by the importation of strikebreakers and the scheme went ahead.

As a result of the progress made by employers towards regularising labour relations in the port and strengthening the hold of the dockers' and seamen's unions over their members, it now remained only to formalise their own association. Up to that time they had entered into individual agreements with the union, albeit on an agreed basis, rather than surrendering the rights to negotiate on their behalf to a collective employers' body. However, a grouping of employers requires some powers to preclude firms from bargaining with unions on their own

1 Ibid., 19 July 1911.

${ }^{2}$ For details see R. Williams, The First Year's Working of the Liverpool Docks Scheme (Liverpool, 1914).

${ }^{3}$ Journal of Commerce, 13 July 1912.

4 Employers' Association of the Port of Liverpool, Minutes of a General Meeting, 12 March and 12 February 1915.

5 Journal of Commerce, 17 July 1912.

${ }^{6}$ Cunard Papers, Booth Files, letter from J. Sexton, 28 August 1911.

7 Journal of Commerce, 17 and 18 July 1912. 
account, because separate negotiations represent a threat to the ability to protect and adhere to an agreed policy.

Thus, in October 1913 a new organisation, the Employers' Association of the Port of Liverpool, was constituted on a vertical basis to embrace shipowners, shiprepairers, master porters and stevedores, master carters, and tug and barge owners. ${ }^{1}$ It was to have four permanent sub-committees comprising two dock labour (one for negotiating and one for organising), one seafarers' and one general labour committee. The Association would have power to impose fines on members who exceeded the agreed terms and conditions negotiated with the unions. Members were required immediately to communicate to the secretary any new demands submitted and not to concede without the authority of the managing committee. ${ }^{2}$ The old practice of paying bonuses for long-serving men was permitted to continue, provided they were paid "for sufficient reason and not merely as a colourable means of exceeding the standard rates of pay". ${ }^{3}$ But a severe line was adopted with members who broke the rules by paying enhanced rates or "subbing" the men; some were fined and others compelled to resign. It was pointed out that it would be impossible for the various committees to work through the union leaders if individual firms undermined their authority by giving way to direct labour agitation; such conduct "could only lead to chaos in the wages of the Port". Union wage claims submitted through the Seafarers' or Dock Labour joint committees were subsequently referred to a representative meeting of the Association for consideration. At the start of the war a claim for an additional $£ 1$ per month for seamen, consequent upon the increased dangers to merchant shipping, was rejected outright despite the fact that Pacific Steam Navigation, Cunard and the Allan Line were all experiencing difficulty in raising crews. It was agreed to take a firm stand and "give way in no case to the demand", by "resisting unitedly". 5

The Association represented about one third of the country's oceangoing tonnage, and was thus in a position to wield strong influence with the Ministry of Shipping during the wartime emergency arrangements. Yet it chose to remain outside the National Maritime Board, set up by the authorities to deal with wages and labour supply, and refused to be represented on that body alongside the Shipping Federa-

1 Employers' Association of the Port of Liverpool, Commitee Minutes, October 1913 - January 1914.

2 Ibid., 10 November 1914.

3 Ibid., 23 December 1913.

4 Ibid., 1 February 1916.

5 Ibid., 10 November 1914. 
tion. ${ }^{1}$ The Board was to regulate the employment of seamen through a single source of supply jointly controlled by the union and employers. The objection of the Liverpool Association was that this arrangement would thereby strengthen the hand of the union by virtually preventing shipowners from exercising their rights of getting a crew as they pleased. Furthermore, given the wide variation between port rates (by as much as $20 \%$ on the maximum), the Association was strongly opposed to the Board's granting a national wage for seamen, uniform in all ports, as it felt that this would lead to a levelling up process to Liverpool's disadvantage. Similarly, it saw no advantage in the Board's conciliation role as its own Seafarers' Committee was quite capable of adjusting disputes in the port. The major criticism seemed to be that the whole scheme had been imposed upon shipowners by the authorities, rather than being self-generated from within the industry. ${ }^{2}$ Only when the Board had been reconstituted after the war, without a government representative, did the Association finally agree to be represented. ${ }^{3}$

\section{IV}

In this paper we have traced the origins and development of associations in Liverpool which sought to promote employer interests in labour matters from the early, primitive relationships of belligerency and uncompromising stance towards trade unions in the 1890's to the initiatives of the 1911-14 period, when the unions became recognised and joint machinery was set up for the more orderly conduct of industrial relations. Both the ELA and the Shipping Federation had been formed at a time of acute labour crisis in an attempt to stop the unions in their tracks. A similar approach was followed at some continental ports such as Marseilles, where, "in a moment of panic", the Union Patronale Marseillaise was formed with a fighting fund. ${ }^{4}$ Later, in 1909, an international grouping became established through the International Shipping Federation. In contrast, the recognitions of 1911 in Liverpool were granted before the general transport strike

1 The Liverpool Association felt that the minority of liner members in the Shipping Federation did not fully appreciate what had been undertaken on their behalf. In fact, the Mersey District of the Shipping Federation was totally opposed to the arrangements, maintaining that "to agree to act with the union would be to give away the fundamental basis of the existence of the Federation", Shipping Federation (Mersey District), Minutes, 22 October 1917.

2 Employers' Association of the Port of Liverpool, Committee Minutes, 12 September 1917.

3 Ibid., 20 December 1918.

4 Journal of Commerce, 23 May 1901. 
of that summer, not so much because the employers' hand was forced - they could have held out longer - but because employers adopted a realistic and more forward-looking strategy to put labour relations in the port on a stable footing, once and for all. Recognition was granted on a permanent basis, not as a tactical concession to be withdrawn when labour conditions became less favourable. Competitive conditions were now significantly different from those twenty years earlier. Concentration of business units in shipping had gone further at this time on the Mersey than on the Thames, ${ }^{1}$ and the firms had developed an accommodation and amicable working arrangements between themselves to regulate trade, especially on the North Atlantic routes so as to meet competition from German lines. The one remaining weak point was the uncertainties produced by the labour situation in the port.

Employers therefore began to take labour relations more seriously and boards of directors rather than general management now made the important decisions. They had come to realise that the union could prove a useful adjunct to them in the conduct of their business. Unlike the railway companies which refused recognition, to prevent being in the cleft stick of having to raise wages against rigidly controlled revenues, ${ }^{2}$ the Liverpool steamship lines were at once able to increase both passenger and freight rates by $10 \%$ to recoup the costs of higher wages arising from the settlements. ${ }^{3}$ Thus, recognition was to be the start of a continuing relationship with the unions, and it brought about a new era of collective bargaining and joint regulation.

1 E. Hobsbawm, loc. cit., p. 213.

2 E. H. Phelps Brown, op. cit., p. 300.

3 Journal of Commerce, 18 July and 20 September 1911. 